\title{
Assistive Technology Divide: A Developing Country Perspective
}

\author{
Allen Nnanwuba Adum \\ Department of Mass Communication, \\ Nnamdi Azikiwe University, Awka, Anambra State, Nigeria \\ Ogochukwu Ekwenchi \\ Department of Mass Communication, \\ Nnamdi Azikiwe University, Awka, Anambra State, Nigeria \\ Ojinime Ebelechukwu Ojiakor \\ Department of Mass Communication, \\ Nnamdi Azikiwe University, Awka, Anambra State, Nigeria \\ Gloria Nwakego Chukwuemeka \\ Department of Mass Communication, \\ Nnamdi Azikiwe University, Awka, Anambra State, Nigeria
}

\begin{abstract}
Use of ICTs, in relation to physical challenge, especially visual impairment, is a problematic issue. This study explored awareness, accessibility and use of specialized ICTs among visually impaired adults in selected urban cities in South- eastern Nigeria. Thirty In-depth Interviews were conducted among visually impaired students and government employees. The study established a general awareness of ICTs, and limited awareness of specialized ICTs, among these visually impaired persons. It also found that use of specialized ICTs among them appeared a distant reality. This led to the conclusion that a 'divide' exists in terms of accessibility and use of assistive technology for the visually impaired persons in this region. The study recommended individual and governmental interventions, to help bridge this 'divide'.
\end{abstract}

Keywords: $\quad$ Assistive Technology Divide, Visually Impaired, Specialized ICTs.

DOI: $10.7176 / \mathrm{DCS} / 9-4-13$

Publication date: April $30^{\text {th }} 2019$

\section{Introduction}

I was in the examination hall invigilating my students. Out there, just to a corner of the auditorium, a visually impaired student was tapping hard at the keys of an old-fashioned Japanese-made Brother Typewriter. The sound of tat ta-ta-ta tat ta-ta tat rented the air, intermittently. I got close to her and observed that the output on her typing sheet was jumbled up. I began to wonder, in this age of ICTs, wouldn't a specialized computer and printer make studies and exams a lot easier for this physically challenged person? Quietly, I spoke to her in Igbo language, "Mercy, imara na computer puru iche, nwe ike inyere gi aka ide ule gi?" (Meaning: Mercy, do you know that a specialized computer can be helpful in your exams?) A gentle smile crossed her face, as she replied, "ebeni ka onye di kam ga enweteni ya o! (Meaning: where would a forgotten one like me get such?). I could sense the despondency. The challenge, the visually impaired faced in their bid to live normal lives, suddenly dawned on me. Yes, assistive technology abound. This means there is potential help for the physically challenged in the world. But for people like Mercy, in a developing country like Nigeria, assistive technology is still a dream.

In the history of humanity, attempts have been made at one time or the other to assist the physically challenged to live normal lives. The Braille system which was developed over 200 years ago, was meant to assist the visually impaired to engage in written communication (Daniels 1996). Louis Braille, the inventor had an 
accident, at age three, which deprived him of his sight. Realizing that he was locked out of the vast world of thought and ideas because of his disability, and being desperate to read, Braille developed a system of tactile communication using raised dots (Mellor, 2006).

According to the World Health Organization [WHO] (2011), there are 285 million people with vision impairment worldwide; comprising 246 million with low vision and 39 million who are blind. These millions of visually impaired people usually depend on written information that has been translated into Braille or audio books, which take quite some time to produce.

ICTs help individuals, businesses and organisations to use information. ICTs revolve around any device that will store, retrieve, manipulate, transmit or receive information in a digital form. Electronic devices like personal computers, digital television, phones, robots, etc form the basis of ICTs (Access IT University of Washington, 2010).

ICTs, especially the Internet, can be invaluable to visually impaired persons, who could be empowered to independently complete tasks, such as reading mails or managing bank accounts, which they would normally not be able to accomplish without help from other people.

Assistive technology helps individuals with disabilities to perform functions that might otherwise be difficult or impossible. Assistive technology includes mobility devices such as walkers and wheelchairs, as well as hardware, software, and peripherals that assist people with disabilities in accessing computers or other information technologies (Access IT University of Washington, 2010). For instance, people who have limited hand function may use a keyboard with large keys or a special mouse to operate a computer. People who are visually impaired may use software like JAWS (Job Assist With Speech) that reads text on the screen in a computer-generated voice, or software that enlarges screen content. Those who are deaf may use a TTY (text telephone), and those with speech impairments may use a device that speaks out loud as they enter text via a keyboard (Access IT University of Washington, 2010).

Specialized ICTs for the blind usually involve assistive technology which gives persons with visual impairment the ability to communicate better. These devices (see appendix) include:

- Bank note reader: This hand-held electronic device can digitally assist visually impaired persons to recognize banknotes.

- Audio play back equipment: This is a portable digital audio book player which helps visually impaired students to increase their reading speed, comprehension and vocabulary.

- Refreshable Braille display: This is an electro-mechanical device for displaying Braille characters, usually by means of raising dots through holes in a flat surface. Visually impaired persons, who are not able to use a normal computer monitor, may use it to read text output.

- Screen readers: This is a software application that identifies and interprets what is displayed on computer screen.

- Braille note taker: These are portable electronic devices with Braille keyboards that are used for entering information, and a speech synthesizer or Braille display for output.

- Speech synthesizer: The speech synthesizer is a device that is used to translate text characters into sounds that mimic human speech.

- Braille printer: The Braille printer is a device which embosses Braille onto paper. Braille printers are akin to ink printers but differ only in their use of solenoids to control embossing pins.

- Mobile phone for the visually impaired: This is a specialized phone designed specifically for those who are blind. It has features like Braille keypad and speaking interfaces.

Many services in our globalised world society are digitized. Being able to access and use information and communication technologies (ICTs) has become a prerequisite for independent living and participation in the scheme of things in an ICT -driven world. The ability of persons with visual impairment to access and use assistive ICTs, therefore, would place them in good stead to fully live out their lives in a digitized environment. 
Societies in most developing nations such as those in Africa look at disabilities as burdensome. Such disposition put the physically challenged at some disadvantage. In a technology- based world, if people with disabilities, like the visually impaired, especially in developing societies, are not abreast with technological trend, they might find themselves denied the opportunity of getting good education and even jobs.

This paper therefore presents the issue of assistive technology divide from the perspective of the experiences of a select visually impaired students and workers in Nigeria

\section{Objective of Study}

The objective of this study was to explore awareness, accessibility and use of ICTs among visually impaired adults in selected urban cities in the south eastern region of Nigeria. The study sought answers to the following questions:

1. Are the visually impaired adults in major urban cities in south eastern Nigeria aware of ICTs generally?

2. Do they know that specialized ICTs for the visually impaired exist?

3. Do they own these specialized ICTs?

4. Do they have access to these specialised ICTs?

5. Do they make use of these specialized ICTs?

\section{Literature Review}

Technological innovations are becoming more advanced. New technologies continue to develop, especially in the realm of information and communication. The availability of computers and the Internet has raised the issue of accessibility. This is especially so for physically challenged people like the visually impaired.

Technological Determinism states that media technology shapes how we as individuals in a society think, feel, act and how our society operates as we move from one technological age to another (McLuhan, 1962). Also, Rodman (2001) defines Technological Determinism, as a theory that states that the introduction of new technology changes society, sometimes in unexpected ways.

It is inherently difficult for persons with visual impairment to receive, perceive, or interpret visual information. This inability precludes these physically challenged persons from participating, in a meaningful way, in today's knowledge-based economy. Pike (2003) therefore holds that the future jobs of thousands of these visually impaired persons, their ability to use labour saving household appliances, and their capacity to deal electronically with the rest of the world is at stake.

ICT implies using computers, mobile phones and other digital devices to access and share information. ICT systems use screen based technology to present information. This means that the visually impaired might find it challenging to read from the screen; follow diagrams and charts; use email, browse or blog; and, store and organize information on a personal computer or phone. Assistive technology offers possibilities that could make life a lot easier for the visually impaired. But there are concerns of accessibility and competencies.

Abner and Lahm (2002) investigated the extent to which visually impaired students in the U.S. use assistive technology. Findings show that visually impaired primary and secondary students across the United States had not been trained to use assistive technology in public schools. This means that the competency required to access such technology is denied. According to American Foundation for the Blind (2005), a good majority of these students attend the same regular public schools, sit in the same classrooms, and have the same teachers as do their sighted counterparts. This means no special provision is made to assist their education, since they are included in regular education as prescribed by American law.

Visually impaired students need textbooks in Braille or large print. Smith, Gerushchat and Huebuer (2004) found that, regardless of the U.S. Education Act which mandates equal and timely access to information presented in 
school to all categories of students, there was consistent delay in making Braille materials and large prints available to visually impaired students.

Kapperman, Sticken and Heinze (2002) suggest that students with visual impairment in the U.S. state of Illinois, were not receiving the experience the required in order to use assistive technology.

Thurlow, Johnstone, Timmons and Altman (2009) found a pressing need for technology-based reading assessment for the visually impaired in the U.S.

Kelly (2009) investigated the use of assistive technology by visually impaired students in the United States. Findings show that a majority of these students were not using assistive technology.

Mong and Cohen (2011) reveal limited content knowledge amongst teachers using assistive technology in Singapore. This results in inconsistencies and inadequacies in the delivery of instruction. It also reveals that students instructed with assistive technology displayed a mixed range of abilities ranging from little to basic knowledge.

The assistive technology market in advanced societies is replete with devices which could make the visual world accessible to persons with visual impairment. But from the foregoing literature there appears to be a problem of accessibility to this available technology. This portends a divide.

Ugodulunwa (2011) notes that visually impaired students in Nigeria are required to do their assignments, tests, examinations and write their research project report like other normal students. This goes on without provision of specialized ICTs that can enhance their performance at their studies. Against the backdrop of the dearth of specialized ICTs, Ugodulunwa (2011) recommended the need to provide both hardware and software to meet the needs of visually impaired students.

Assistive technology can play a major role in enabling persons with visual impairment to engage in their occupations of choice and participate fully in their community (Polgar, 2001). Assistive technology competency promotes independence for end users (Ivanoff \& Sonn, 2005).

Visually impaired people are, arguably, the most marginalized group, and are drastically affected by the visual bias of the information technology industry. This leaves us with a digital divide on two distinct poles: the technology "haves" and "have nots". The availability of information technology does not necessarily ensure equitable access to information (Goggin and Newell, 2003).

Lucky and Achebe (2013) suggest that placing ICTs in the hands of visually impaired persons help them to fully participate in the world, since they are provided with the best possible support that helps them to have meaningful existence. It further holds that careers in the sciences could be pursued by visually impaired persons as a result of ICT accessibility and literacy.

\section{Method}

A purposeful decision was made to limit this study to the south eastern region of Nigeria. This was done with the belief that further studies would reveal what obtains in other regions. The capital cities of the five states in this region were selected for this study. These cities are: Abakaliki, Awka, Enugu, Owerri, Umuahia. The study was designed as in-depth interview (IDI). This design was necessitated because the study was meant as a rapid assessment of what obtains in the region under study. The study population is 3668 visually impaired persons. Six individual depth interviews were conducted in each of the selected urban city; three with visually impaired tertiary students and three with government employees. In all, there were 30 interviews. The interviews sought to elicit answers from the respondents with regard to: their awareness of ICTs generally; their knowledge of the existence of specialized ICTs for the visually impaired; ownership and access to these specialized ICTs, as well as their use of these devices. 


\section{Results and Discussion}

The qualitative data generated from these 30 IDIs, spread across five urban cities in South-eastern Nigeria, offer a wide range of preliminary conclusions. It is hoped that future studies, based on a more experimental hue, would make for more experimental results that would lead to wider conclusions.

Research question 1 asked: are the visually impaired adults in major urban cities in south eastern Nigeria aware of ICTs generally?

The idea of the information age would suggest that novelties are easily made known to individuals from one end of our planet to the other. When we had the Y2K 'phobia', it did not take time to belt the globe. This caused a near panic, midnight 1999. Along this line, data obtained from interviews with visually impaired persons in south eastern Nigeria show that they are generally aware of ICTs. The response of a visually impaired Anambra state government employee summed it up:

Well, whoever knows something about ICT would know that this age is a [the] computer age. The importance of the Internet should not be overemphasized. Through the Internet the world is a global village. Through the Internet, you can get any information. Those in the labour market, health, agricultural sector; Internet makes the world a global village. That's all I can say.

Since we are in the information age, it might not be least expected that the visually impaired would be aware of ICTs. Many of the visually impaired students and government employees interviewed understood ICTs from the standpoint of the ability to use the computer and the Internet. The following highlights encapsulate the cumulative gist of their responses:

A computer does a lot of functions. It helps in typing of materials. It helps in the banks; without it we can't access accounts. It helps in the UME [Universities Matriculation Examination] uploads.

The Internet is very important to human life. It is a very necessary something. We need Internet to get Information.

Research question 2 sought to know whether these visually impaired adults knew about the existence of specialized ICTs for the visually impaired such as Bank Note Reader, Audio Playback Equipment, Refreshable Braille Display, Screen Reader, Braille Notetaker, Speech Synthesizer, Braille Printer, Braille Mobile Phone. While most of these visually impaired persons found some of these devices strange, quite a handful knew about them. These ones had either heard about them through friends or got to know that they exist through the Internet. Along these lines, some highlights from the IDIs are as follows:

I make use of some persons around; the technology [bank note reader] is not available in this country.

Don't know; I have not heard about it [bank note reader].

I don't know about audio playback equipment.

Well, a refreshable Braille display is [the] equipment that actually brings Braille dots on your device, so whatever type of Braille cells that you have is brought up.

JAWS now...? Is that not JAWS? It's JAWS that I know very well. 
I have heard of them [Screen reader].

I'm not aware of that [Braille note taker]; it's strange to me.

I have heard about it [Braille note taker], but don't know how it works.

Speech synthesizer or JAWS or TAKS are attached to your device or computer and they aid voice commands.

Braille printer - that's the Embosser. It's like a printer. Once you connect your computer to the embosser it comes out with embossed printout.

I have heard about it but I have not seen it. I have read about it on the Internet. I know they have Braille cell phones.

I have heard my friend mention it [Braille mobile phone]; but I have not seen it.

As earlier mentioned, it doesn't seem to take a long while to get modern trends round to everybody. Today people talk about blackberry, iPhone, iPad etc; or actually own them! But, not prioritizing specialized ICTs means that they seem a distant reality to some visually impaired persons as revealed by these IDIs in Nigeria's south east region.

Research question 3 sought responses that would show that these persons with visual impairment own specialized ICTs. There were few suggestions here and there that these persons had conventional devices with some features that could assist them to communicate, but not the specialised devices purpose-made to assist the visually impaired to communicate and live better. The following highlights reflect this observation:

My phone has a lot of accessories. I send sms; multimedia messages with my picture with the help of my friends.

I only use my phone to answer calls or make calls and voice commands.

I have one [computer] that has voice system.

The overall picture here is that, the general non availability of specialized ICTs for the visually impaired could be responsible for many of these persons not owning these devices; rather they depended on conventional devices with some features that help them to communicate.

Research question 4 asked to know how accessible these specialised ICTs are to these visually impaired persons. Ordinarily, in a situation where priorities are set right, the school and office settings are critical places that could afford the visually impaired access to specialized devices. But this happens not to be the case in this region. A visually impaired law student at the Nnamdi Azikiwe University, Awka, puts it this way:

These things are still far away from my reach.

Also, an employee of the Imo State civil service summed it up this way:

I have heard the theory aspect of it; I don't have access to them.

Evidently, for these visually impaired persons, there is a challenge of accessibility to specialized devices like the bank note reader, screen reader, Braille mobile phone, among other devices. "These things are still far away from 
my reach", would suggest that these devices are distant realities to many of the visually impaired persons within this region covered.

Research question 5 sought to know whether these visually impaired persons made use of specialized ICTs. The response of one of the visually impaired workers at the Enugu State civil service gave the overall picture in this regard:

I have heard about computer but I have not used it; because of the situation in the country; because of my handicapped situation. All I need to make me use the computer have not been made available.

The suggestion here is that, these visually impaired persons, being aware of ICTs generally, are keen on having their lives bettered by the use of assistive technology; but the problem seems to be that nobody has cared enough to want to make available these devices to them. This need appears to be embedded in the following comments from the IDIs:

I would commend you for your research. The questions you have put to me have opened my eyes to the world of computer and I will go looking for them. That's what you have done for me.

It's very commendable to research on specialised ICTs; I will study more about it. I'll expand on the topic.

\section{Summary and Conclusion}

The overall picture, against the backdrop of the objective of the study, is that, for the visually impaired persons who were studied, there is general awareness of ICTs; and, to some degree awareness of specialized ICTs. Also, ownership and access to these specialized ICTs among them is almost equal to zero, while the use of them appeared a distant reality.

The implication from these conclusions is that, since it would appear that the visually impaired in advanced societies are the 'haves', as far as assistive information and communication technologies is concerned, and their counterparts in Nigeria are the 'have nots', then a divide exists. And, there also exists the need to bridge this divide in order to help these physically challenged people live as normal lives as possible.

\section{Recommendation}

This study recommends that there should be an honest effort to prioritize the provision of technological innovations to the physically challenged in the society to help them live more meaningful lives. For instance, this exploratory study has shown that little is available to the visually impaired as far as assistive technology is concerned. Therefore, individuals, Non Governmental Organizations [NGOs] and the government in particular should champion the case of providing assistive technology to the visually impaired, so that they could live full lives and contribute their own quota to the society.

The visually impaired, as much as Louis Braille did, yearn to be independent. The ability to access and use assistive technology could do much to help satisfy this yearning.

\section{References}

AccessIT University of Washington (2010). What is assistive technology? Retrieved July 31, 2012 from http://www.washington.edu/accessit/articles?109.

American Foundation for the Blind. (2005). An overview of services. Retrieved July 25, 2012, from http://www.afb.org/diroverview.asp.

Daniels, P. (1996). Analog and Digital Writing. The World's Writing Systems, p 886. 
Goggin, G. \& Newell. C.J. (2003). Digital Disability. Rowman \& Littlefield: Lanham MD.

Ivanoff, S., \& Sonn, U. (2005). Assistive Devices in Activities of Daily Living Used by Persons with Age-Related Macular Degeneration: A Population Study of 85-Year-Olds Living at Home. Scandanavian Journal of Occupational Therapy, 12 (1),10-17.

Kapperman, G., Sticken, J., \& Heinze, T. (2002). Survey of the Use of Assistive Technology by Illinois Students who are Visually Impaired. Journal of Visual Impairment \& Blindness, 96, 106-108.

Kelly, S. M. (2009). Use of Assistive Technology by Students with Visual Impairments: Findings from a National Survey. Journal of Visual Impairment \& Blindness, 103(8), 470-480.

Lucky \& Achebe (2013). Information service delivery to the visually Impaired: A case study of Hope for the Blind Foundation, Wusasa, Zaria, Nigeria. Research Journal of Information Technology, $5(1), 18-23$

McLuhan, M. (1962) The Guternberg Galaxy: The Making of Typographic Man. Toronto: University of Toronto Press.

Mellor, C.M. (2006). Louis Braille: A Touch of Genius. Boston: National Braille Press.

Polgar, M. J. (2001). Using Technology to Enable Occupation. Occupational Therapy Now, 9, 23-25.

Pike, G. (2003). Disability Access and the Internet. Information Today, 20(2), 19-20.

Rodman, George. Making Sense of Media. Boston: Allyn and Bacon, 2001.

Smith, A. J., Gerushchat, D., \& Huebner, K. M. (2004). Policy to Practice: Teachers' and Administrators' Views on Curricular Access by Students with Low Vision. Journal of Visual Impairment \& Blindness, 98, 612-628.

Thurlow, M., Johnstone, C., Timmons, J., \& Altman, J. (2009). Survey of teachers of students with visual impairments: Students served and their access to state assessments of reading. Minneapolis, MN: University of Minnesota, Technology Assisted Reading Assessment.

Ugodulunwa, C.A. (2011). Challenges in the Educational Assessment of Visually Impaired University Students. Retrieved August 30, 2012 from http://dspace.unijos.edu.ng.

World Health Organization (2011) Visual impairment and blindness. Fact Sheet N282. 


\section{Appendix}
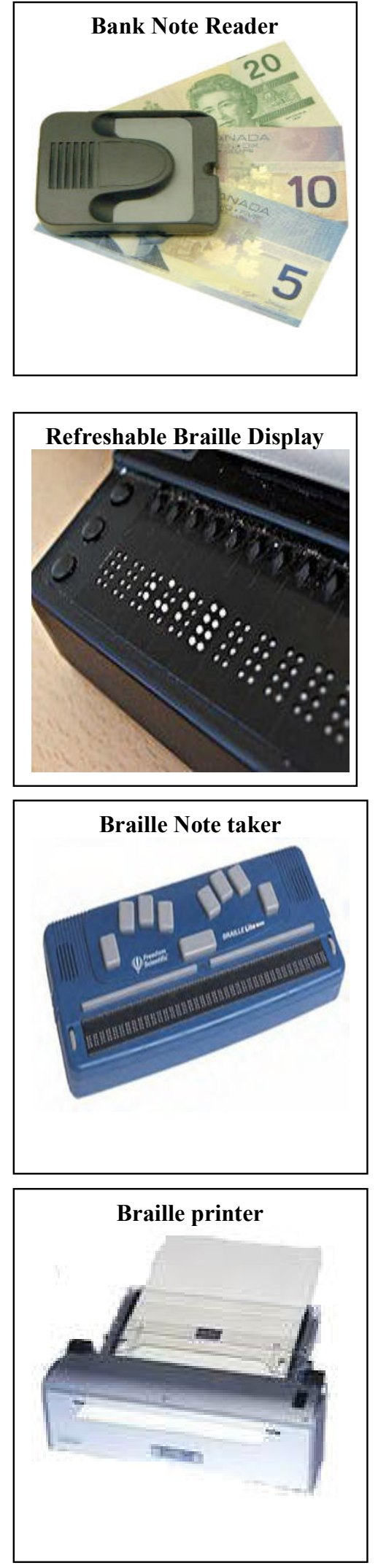
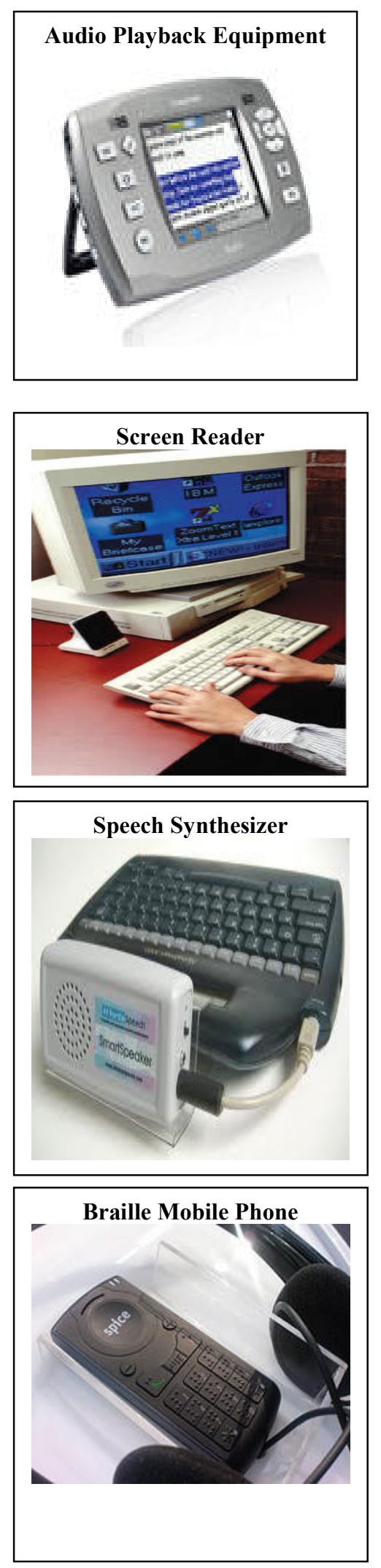